\title{
STUDYING OF INACTIVATED VACCINE EFFICIENCY AGAINST NEWCASTLE DISEASE IN BROILER CHICKEN
}

\author{
NAWAL KHALED ALKARAWANI \\ Dept. Animal Diseases, Phd in Poultry Diseases, Faculty of Veterinary Medicine \\ University of Hama, Hama - SYRIA
}

Received: 31 December 2016; Accepted: 16 January 2017

\begin{abstract}
Field study was conducted on a flock of broiler chicken in the city of Hama to evaluate the effectiveness of vaccination programs against Newcastle disease, which are used by the live vaccine or the both live and inactivated (inert) vaccine. The flock were divided into two groups, the first have immunized by live vaccine only. Second group were have vaccinated by both live and inactivated vaccine (inert) in age 6 days for both groups. Re-immunization was applied on both groups by live vaccine in age of 26 days. The study showed the effectiveness of the partnership between the two vaccines live and inactivated (inert) were better than the live vaccine only, and the re-vaccinated at age 26 day led to the improvement of the level of the immunity response and the formation of better protection.
\end{abstract}

Key Words: Inactivated Vaccine, Efficiency, Newcastle, Broiler, Chicken.

$$
\text { دراسة تأثير اللقاح الزيتي لمرض النيوكاسل على دجاج اللحم }
$$

Email: nawalqarawany@gmail.com Assiut University web-site: www.aun.edu.eg

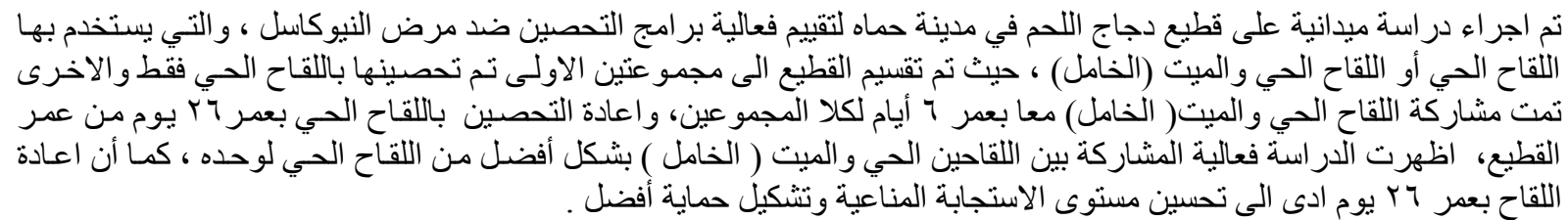

\section{INTRODUCTION}

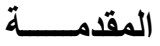

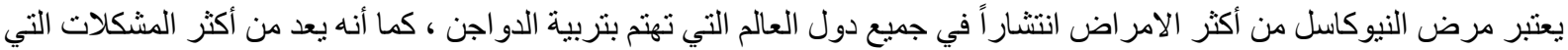

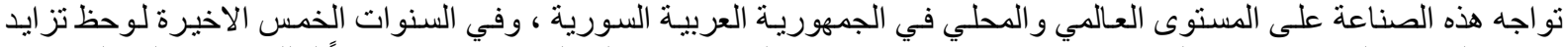

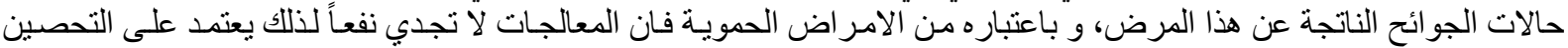

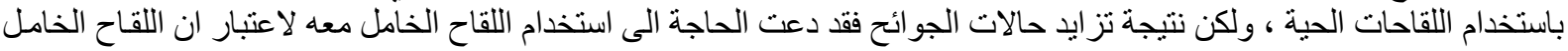

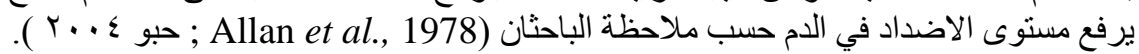

تعد حمة النيوكاسل والتي تتنمي الى جنس OIE, 2000; Alexander...) Rubulavirus) من عائلة الحمـات نظيرة المخاطية هي العامل المسبب لمرض النيوكاسل لتئ عند الدواجن جن ، و تم عزلها لأول مرة عام 1926.

تقسم حمة النيوكاسل الى تسعة أنماط مصلية هي PMV1 الى PMV9 ، وتعتبر PMV1 هي أشند الانواع الملية امر اضية وأخطر هـا على تربية الدو اجن.

Corresponding author: Dr. NAWAL KHALED ALKARAWANI

E-mail address: nawalqarawany@gmail.com

Present address: Dept. Animal Diseases, Phd in Poultry Diseases, Faculty of Veterinary Medicine University of Hama, Hama - SYRIA. 


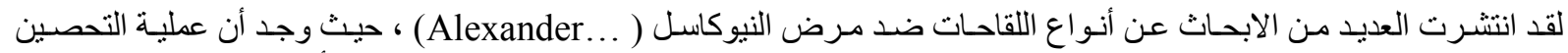

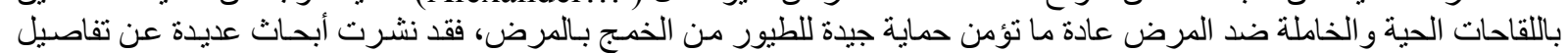

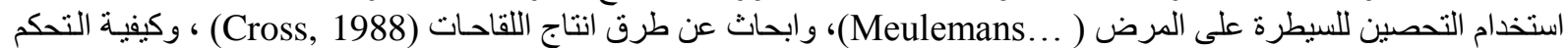
بالمرض عن طريق استخدام اللقاحات (Thorntorn, 1988) كما أدى أكتشاف المرض فرض في الو لايات المتحدة الى استخدام اللقاحات

الخاملة في التحصين (Hofstad, 1953).

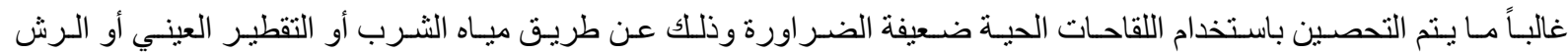

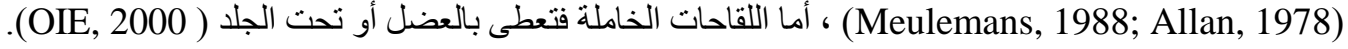

تعطي اللقاحات الحية مناعة موضعية متمثلة بالغلو بيولين المناعي AIg ، اما اللقاحات الخاملة فتحدث مناعة دموية والتي تستمر لفترة أطول وبمعدلات عالية (Calnek et al.,1999; Gough et al.,1977).

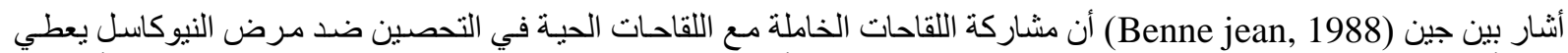

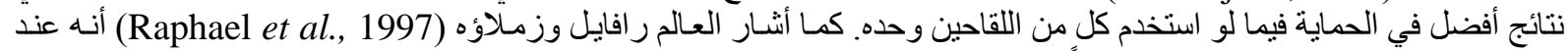

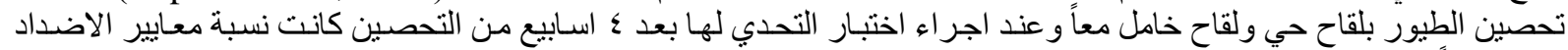

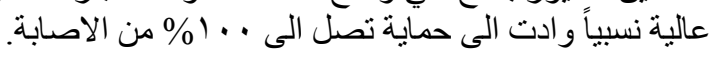

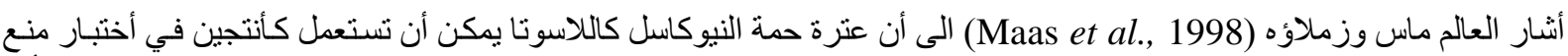

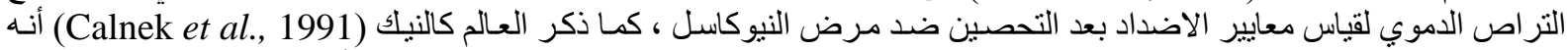

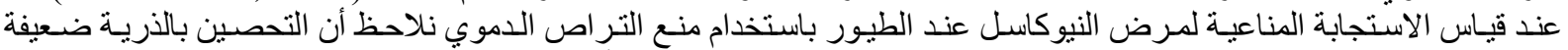

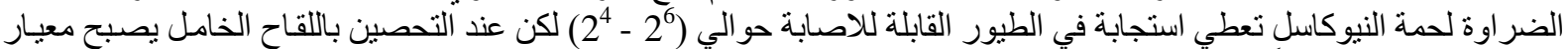

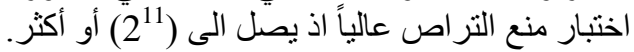

تهدف الدراسة الى تقييم فعالية اللقاح الزيتي الخامل عند مشاركته مع اللقاح الحي للتحصين ضد مرض النيوكاسل في دجاج اللحم.

\section{MATERIALS AND METHODS \\ المواد والطرائق}

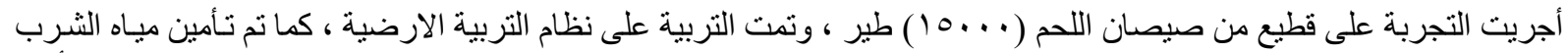

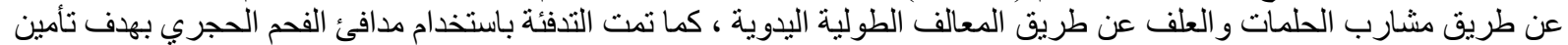
الحر ارة اللازمة و المناسبة بحسب كل مرحلة من مر احل التربية.

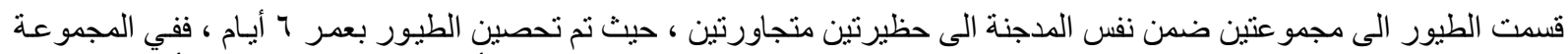

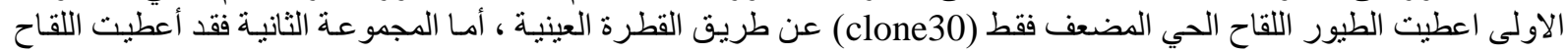

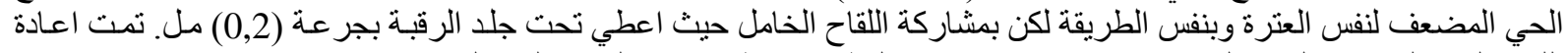

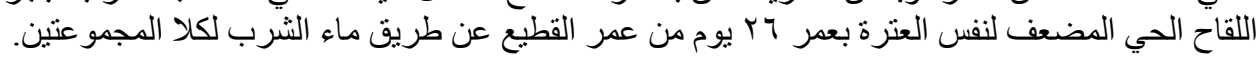

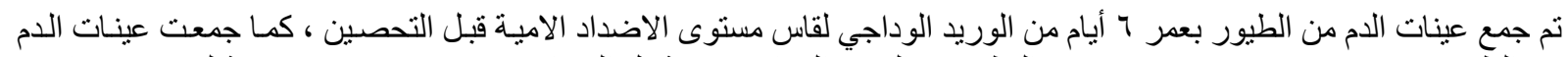

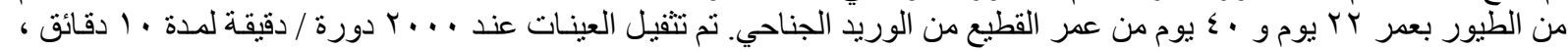

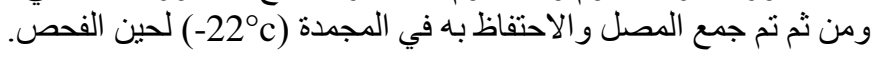

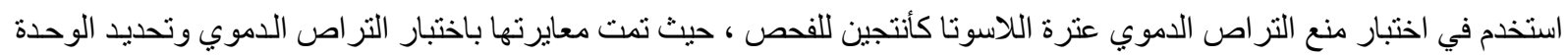

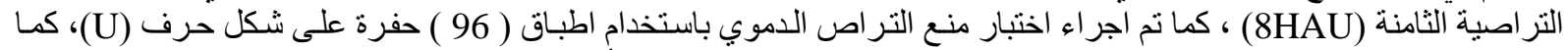

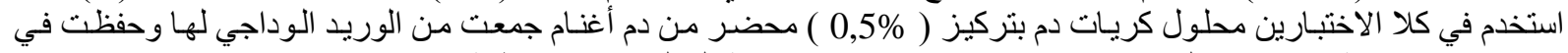

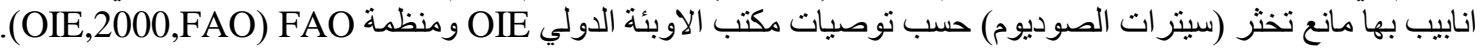




\section{RESULTS}

النتائستج

عند فحص الصيصان بعدر 7 أيام تبين عدم تجانس المناعات الامية حسب الجدول التالي:

\begin{tabular}{|c|c|c|}
\hline العدد & رقم الحفرة & العيار \\
\hline$r$. & $r$ & $r \cdot / l$ \\
\hline r. & $r$ & $\varepsilon \cdot / 1$ \\
\hline$r$. & $\varepsilon$ & $\Lambda \cdot / 1$ \\
\hline 1. & 0 & $17 \cdot / 1$ \\
\hline 1. & 7 & $r r \cdot / l$ \\
\hline$r$. & V & $7 \varepsilon \cdot / 1$ \\
\hline$\varepsilon$. & 9 & ro7./ \\
\hline
\end{tabular}

و عند معايرة الاضداد بعمر ب r يوم من عمر القطيع كانت النتائج كالتالي:

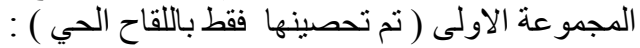

\begin{tabular}{|c|c|c|}
\hline العدد & رقم الحفرة & العيار \\
\hline 7. & 1 & $0 / 1$ \\
\hline 1. & $r$ & $r \cdot / l$ \\
\hline
\end{tabular}

المجمو عة الثانية ( تم تحصينها باللقاح الحي و الميت (الخامل) معاً ):

\begin{tabular}{|c|c|c|}
\hline العدد & رقم الحفرة & العيار \\
\hline 1. & v & $7 \varepsilon \cdot / 1$ \\
\hline ^. & 9 & $r 07 . / 1$ \\
\hline
\end{tabular}

و عند العمر · • يوم كانت النتائج كالتالي:

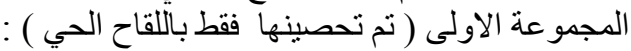

\begin{tabular}{ccc}
\hline & العيار \\
\hline$\varepsilon$ & 0 & $10 \cdot / 1$ \\
\hline$r$ & $r$ & $r \cdot / 1$ \\
\hline
\end{tabular}

المجمو عة الثانية ( تم تحصينها باللقاح الحي و الميت (الخامل) معاً ):

\begin{tabular}{|c|c|c|}
\hline العدد & رقم الحفرة & العيار \\
\hline 0. & $\wedge$ & $1 \mathrm{rA} \cdot / 1$ \\
\hline$\varepsilon$. & 9 & ro7./1 \\
\hline
\end{tabular}

\section{DISCUSSION}

\section{المناقشة}

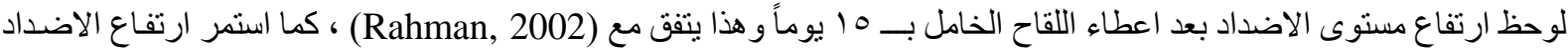

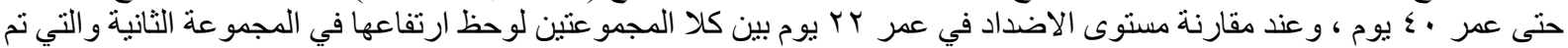

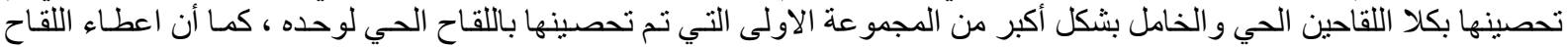

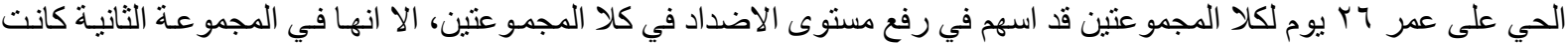

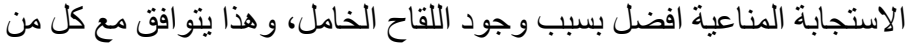


(DoIL et al., 1950; Hfstad, 1954; Winter field et al., 1957; Bran et al., 1959; Hoekstra, 1961; Carrnga et al., 1972; Yamano \& Nakamura, 1974; Wyffels \& Dheedene, 1979; Raphael et al., 1998; King, 1999; Rahman et al., 2002 and Hubbo, 2004).

كما تبين من خلال الدر اسة أنه يجب معر فة مستوى الاضداد الامية قبل عملية التحصين ، فـاذا كان مستوى الاضداد مرتفعاً فيجب

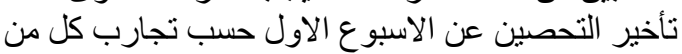

(Yamano\& Nakamura, 1974;Rtshe\&Shmetshl, 1962; Lndgraf, 1972; Awang et al., 1992; Saeed et al., 1988; Fadel, 1984; Gomez \& Ramos, 1978; Rahman et al., 2002; Hubbo, 2004) الاضداد الامية عند التحصين الاولي.

\section{REFERENCES \\ المراجـع}

Alexander, D.J. (1997): Newcastle disease and other. Avian Paramyxoviridae infections.In Disease of poultry, pp 541-569. Edited by B.W. Calnek. Ames, Iowa: Mosby- Wolfe Iowa State University Press.

Allan, W.H.; Lancaster J.E. and Toth, B.(1978): ND vaccines, their production and use. F.A.O Rome 1978163 pp; NO.10.

Awang, L.P.R.; Wan-Ahmad-Kusairy, W.S. and Abdu-Razak, J. (1992): Detection of Maternal antibody against Newcastle disease virus in chicks using an indirect Immunoperoxidase test. J. Vet. Malaysia, 4:19-23.

Benne Jeans, G. (1988): Newcastle disease: control policies. In.

Calnek, B.W.; John Barnes, H.; Beard, C.W.; Reid, W.M. and H.W. Yoder, Jr. (1991): Disease of poultry, $9^{\text {th }}$ ed. Iowa State University Press. Iowa, USA.

Cross, G.M. (1988): Newcastle disease vaccine production. In D.J. Alexander(ed), Newcastle disease, pp:333-346. Lower Academic Publ, Boston.

Crrange, E.; Eleftrescu, Balaci, and Popescu. (1972): Trials of B1 ND vaccine. I (single dose vaccination.II) primary and booster doses.Zootehnie Si Medicina Vet. 22(3) 67-79.

Doll, E.R.; McCollum, W.H. and Wallace, M.E. (1950a): Immunization against ND with a virus of low virulence. Vet. Med. 45, 231.

Gomez, M. and Ramos, P. (1978): Immune response in chicken vaccinated with NDV. Archivosde Med. Vet. 10 (1) 48-55.

Gough, R.E.; Allan, W.H. and Ndelciu, D. (1977): Immune response to monovalent and bivalent Newcastle disease and Infection Bronchitis inactivated vaccines. Avian Pathol. 6:131-142.

Hoekstra, J. (1961): Control of ND and IB by vaccination. Brit. Vet. J.117, 289.

Hofstad, M.S. (1953): Immunization of chickens against Newcastle disease by formalin inactivated vaccine. Am J. Vet Res 14:586-589.

Hubbo, K.R. (2004): Evaluation of vaccination efficiency in broiler chicken using inactivated vaccine against Newcastle disease. Master thesis. Albath University, Faculty of Veterinary Medicine, Syria.

King, D.J.A. (1999): Comparison of the onset of protection induced by Newcastle disease virus strain B1 and fowl poxvirus recombinant Newcastle disease vaccine to viscertropicvelogenic Newcastle disease virus challenge. Avian diseases 43 (4) 745-755 [En. es. 23 ref] U.S. Department of Agriculture.

Maas, R.; Oei, H.L.; Kemper, S.; Koch, G. and Visser, L. (1998): The use of homogous virus in the hemagglotination inhibition assay after vaccination with Newcastle disease virus strain LaSota or Clone leads to an over estimation of protective serum antibody titers. Avian Pathology 27 (6) 625-631.

Meulemans, G. (1988): Control by vaccination. In D.J. Alexander(ed), Newcastle disease, pp: 318332. Lower Academic Publ, Boston.

Office International des Epizooties world organis animal health (2004): Manual of standard for diagnostic test and vaccines.

Raahman, F. (1998): Evaluation of immune response of tow Lentogenic Newcastle disease vaccines given through different routes in chickens. Indian Journal of Comparative Microbiology, Immunology and Infectious Disease 19 (1) 11-13. 
Raphael Folitse, D.A. Halvorson, and V. Sivanandan (1998): Efficacy of Combined Killed In Oil Emulsion and Live Newcastle disease virus in chickens. Avian Diseases 42:173-178.

Saeed, Z.; Ahmad, S.; Rizvi, A.R. and Ajma, M. (1988): Role of maternal antibody in determination of an effective Newcastle disease vaccination program. Pak. J. Vet. Res, 1:18-21.

Thornton, D.H. (1988): Quality control of vaccines. In D.J. Alexander(ed), Newcastle disease, pp: 347-365. Lower Academic Publ, Boston.

Winterfield, R.W. and Seadal, E.H. (1957a): ND immunization studies.2. The immune response of chickens vaccinated with B1 NDV administered through the drinking water. Poultry Sci. 36, 103.

Wyffels, R.E. and Dheedene, J.D. (1979): ND in Moracco. Effect of the vaccination method on circulating antibodies and control of the clinical resistance to infection broilars. Vlaams Diergeneeskundig Tijdschrift 48(6) 506-511 Institut Hassan II.

Yamano, Y. and Nakamura, Y. (1974): Fluctuation in haemagglutination inhibiting antibody titer in chickes inoculated with TCND ND Vaccine Journal of the Japan Vet. Med. 